\title{
The Rise of the Platform Business Model and the Transformation of Twenty-First-Century Capitalism
}

\author{
K. Sabeel Rahman \\ Brooklyn Law School
}

\section{Kathleen Thelen \\ MIT}

\begin{abstract}
This article explores the changing nature of twenty-first-century capitalism with an emphasis on illuminating the political coalitions and institutional conditions that support and sustain it. Most of the existing literature attributes the changing nature of the firm to developments in markets and technology. By contrast, this article emphasizes the political forces that have driven the transformation of the twentiethcentury consolidated firm through the firm as a "network of contracts" and toward the platform firm. Moreover, situating the United States in a comparative perspective highlights the distinctive ways US political-economic institutions have facilitated that transformation and exacerbated the associated inequalities.
\end{abstract}

\section{Keywords}

United States, political economy, platform capitalism, antitrust, consumers

\section{Corresponding Author:}

K. Sabeel Rahman, Brooklyn Law School, 250 Joralemon St., Brooklyn, NY I I 20I, USA.

Email: Sabeel.rahman@brooklaw.edu 
Over the past few years, Uber's controversial corporate culture and practices have raised questions about the firm's long-term vision and sustainability. Despite the turmoil, however, Uber remains one of the most highly valued and influential enterprises in the world. Perhaps more than any other company, Uber has come to stand in for the excesses and promise of twenty-first-century capitalism. Uber drivers are the paragon of the new "gig economy," in which work is increasingly precarious, insecure, and yet highly optimized for both firms and end users. But Uber is not just indicative of a new way of organizing work. It also epitomizes a new form of the firm itself, from its relationship to its investors and driver-"partner" employees to its political presence as an active lobbyist and a studious cultivator of a pro-consumer image.

In the past, megafirms such as General Motors or General Electric employed and provided benefits for a large number of workers across a range of skill and income levels. The model mid-century industrial firm embodied what the philosopher Elizabeth Anderson described as a "nexus of reciprocal relationships" between the firm and its internal and external stakeholders. ${ }^{1}$ That model supported large workforces on permanent employment contracts and concentrated power in the hands of managers whose goal was stable long-term growth. It was underwritten by "patient" capital (in Europe often provided by banks, in the United States by passive and dispersed shareholders) that allowed for the cultivation of long-term relationships and stable gains for all of the company's stakeholders, including labor.

As Gerald Davis, among others, has pointed out, that model broke down in the late twentieth century. ${ }^{2}$ The shareholder revolution shifted power from consolidated firms and powerful managers to investors and securities analysts, transforming the classic mid-century firm into a "network of contracts" (NOC). In the world of shareholder value, stock price was the core metric of success, and share value rested heavily on hitting analysts' quarterly profit projections. Facing intense pressure from investors to focus on "core competencies," firms engaged in aggressive outsourcing, asset stripping, and labor-reducing strategies. Davis coined the term "Nikefication" to denote the radical slimming down to the highest-value-added segments of the production chain and, in the case of Nike, outsourcing virtually everything except the design and marketing functions.

The new vanguard firms of the twenty-first century-not just Uber but also Amazon, Google/Alphabet, Facebook, and others - represent a new type of platformbased business model that builds on the developments of the 1980s and 1990s but combines them with new features. Whereas the previous NOC model centered largely on "price-based competition among producers of relatively similar products," today's platform firms represent a new way to create and capture value. ${ }^{3}$ They do so, above all, through their capacity to extract and harness immense amounts of data in ways that allow them to operate as critical intermediaries and market makers. ${ }^{4}$ Thus, for example, service platforms such as Uber or Upwork provide a link between requesters and providers of services; goods platforms like Amazon connect buyers and sellers of all kinds; and information platforms such as Google and Facebook connect end users to sources of information and media through search, news feeds, and the like. 
Some of these platforms now exercise a level of market dominance that inspires comparison to classic monopolies of the nineteenth and twentieth centuries. But what is distinctive about them is the way they achieve market dominance: the goal for these firms is not so much direct ownership as control. Indeed, compared to the monopolists of yesteryear, today's platform firms in many ways exercise deeper control because of the way the platform's data and algorithms "structure the rules and parameters of action" that are available to participants on the platform. ${ }^{5}$ In this sense, as John Zysman and Martin Kenney point out, these platforms constitute "regulatory structures" that dictate the terms of interaction - between workers and employers, buyers and sellers, clients and contractors, creators and viewers, and advertisers and consumers. ${ }^{6}$ This networked mode of market domination suggests that many traditional measures of a firm's "size" are not refined enough for assessing platform dominance. Indicators such as market capitalization and market share are relevant, of course, but may understate the degree of dominance. Amazon, for example, has a vast share of the retail marketplace; but even more important, it occupies a structural position that enables it to control market flows in both directions.

Today's platform firms do not displace all other existing corporate forms, any more than the previous NOC firm completely eclipsed the stakeholder model (Sears, perhaps the most prominent of the remaining stakeholder firms, only recently succumbed). The platform model does and will continue to coexist alongside other types of firms. Platform firms are important not for their ubiquity, or because all firms do or will look like them, but because they represent the leading edge of emerging business models and, as such, increasingly set the terms of the markets they enter. Airbnb, for example, puts intense pressure on traditional hotels, and Walmart and other traditional retailers such as Macy's survive only by emulating core features of the Amazon model.

Indeed, rather than displace previous corporate forms, platform firms actually often embrace and extend features of those models. Just as the previous NOC firm intensified key aspects of the previous Fordist model — above all, its specialization and division of labor - platform firms build on and intensify features of the NOC model, especially its labor practices. What platform firms such as Uber share with the NOC firm of the late twentieth century is a labor- and cost-cutting strategy that avoids standard employment contracts (and associated social contributions) in favor of indirect employment and "atypical" work arrangements. In fact, platform firms are able to take the cost-reduction strategies of NOC firms to a new level, relying more heavily on independent contracting and deploying their massive data collection capabilities to optimize and manage labor, task by task, with surgical precision.

In short, today's platform firms combine features of previous models with new elements. Moreover, and most important for our purposes, their distinctive features rest on three political-economic enabling factors that set them apart from previous models. First, in contrast to the short-term investor-demand dynamics of the NOC firm, platform firms have benefited from a more "patient" form of capital. Investors played a key role in the NOC model, but the most dynamic new platform firms are backed by a different type of investor with different motives. Unlike the "break it up and sell it off" 
mentality of the 1990s, the financial interests behind firms such as Uber and Amazon are in it for the long haul.

Second, this investor patience is explained by a different business purpose to platform firms. The core of the NOC model was outsourcing and labor shedding as a means to enhance profits and boost share value. By contrast, network effects are the sine qua non of the platform firm. The central goal is to secure a level of market dominance and concentration that will ultimately vindicate investor patience. Indeed, the very idea of the "platform" reflects an aspiration to be the foundational infrastructure of a sector-whether it is Uber's attempt to dominate transportation services from taxis to shipping or Amazon's dominance of the online retail market as a whole.

Once achieved, this "winner take all" market dominance offers many avenues for generating returns through rents while also multiplying the number of stakeholders whose dependence on the platform makes them potential allies in efforts to defend it against unwelcome regulation. This networked dominance is what makes platform firms both a revival and a reinvention of classical monopoly concerns. Like classical monopolies in which increasing returns to scale and high sunk costs enable market concentration, network effects allow platforms to race ahead of potential competitors to secure and defend their market dominance. However, with platforms, that dominance is often hidden from view; it does not always take the more visible form of vertical or horizontal integration that marks traditional antitrust analysis.

A third and final difference has to do with the role of consumers. Consumers were of course already important to the success of the NOC firm as partial beneficiaries of low labor costs leading to low consumer prices. However, consumers figure centrally not just in the market strategies of the platform firm but in their political strategies as well. Compared to the NOC firm, platform firms enjoy a much more direct and unmediated link to their users, most of whom connect to these firms through devices they carry in their pockets every day. The most successful of such firms have proved to be extraordinarily adept in leveraging their loyal consumer base into an active public narrative and political advocacy strategy in order to secure legislative and legal support for the platform business model. These elements- "gig" labor practices, patient capital, market dominance, and alliance with consumers - need not all be present in all instances. But they represent distinctive components of the new platform business model that is increasingly central in shaping the dynamics of modern capitalism.

This article explores the changing nature of twenty-first-century capitalism with an emphasis on illuminating the political coalitions and institutional conditions that support and sustain it. Our focus is on the emergence of the platform business model in the rich democracies, especially the United States, that pioneered these new corporate forms. Most of the existing literature attributes the changing nature of the firm to developments in markets and technology. ${ }^{7}$ Clearly, digital technologies (and the internet itself) were key preconditions for the emergence of the platform business model. However, those technologies had to be adapted and deployed in markets, and here political-economic and institutional forces play a role. So although the relevant technologies have proliferated widely across the globe (and although the new platforms are truly global companies in most respects), the politics associated with these new 
corporate forms have varied between the United States and other advanced industrialized countries. By situating the United States in a comparative perspective, we highlight the distinctive ways in which US political-economic institutions have facilitated the growth of the platform model and exacerbated the inequalities with which it has been associated.

The analysis is organized into three parts. We begin by providing a stylized sketch of the changing nature of the vanguard firm in the advanced capitalist world - from the dominance of the traditional stakeholder firm, through the financialized and fissured firm depicted by Gerald Davis and David Weil, to the current new platform model. Each of these types of firm rests on a somewhat different political-coalitional foundation. Simplifying greatly, the traditional model was based on a coalition of managers and stakeholders including labor. That mid-century firm involved both "patient capital" and the incorporation of labor into the social contract and the governance of the firm. That coalition was replaced by the late twentieth century by a new model resting on a coalition of managers and investors around strategies of asset stripping, radical outsourcing, and soaring CEO pay. Platform capitalism, by contrast, relies above all on an alliance - brokered by powerful CEOs and managers - between firm owners/investors and consumers around a wholly new model of patient capital aimed not at steady growth and shared prosperity, as before, but at winner-take-all market strategies. ${ }^{8}$ The resulting new concentrations of corporate power are consolidated and rationalized under the banner of serving consumer interests. In this way, consumers are enlisted-either explicitly or, more often, implicitly - in the political alliance against labor.

In the second part we explain why the United States has emerged at the forefront of these developments. The US lead in pioneering this new corporate form is often attributed to the country's superior capacity for technological innovation or to a large domestic market that allows megafirms to grow. We acknowledge the contributions of those background factors but draw attention to three further features that have provided an especially congenial political-economic context in which the new corporate model has been able to flourish.

First, platform capitalists have been able to exploit the fragmented policy landscape in the United States to expand networks rapidly to achieve scale in a regulatory landscape marked by decentralization and overlapping regulatory jurisdictions, on the one hand, and weak countervailing organized interests, on the other. Second, the US political economy is characterized by a legal institutional regime that actively nurtures and supports the consumer-investor coalition on which the platform economy is premised. Third, the heavily financialized US political economy is able to provide the abundant sums of patient capital that platform firms require to grow to scale. Thus although the transformations of the firm described in this article are not unique to the United States, we suggest that features of the American political economy have made it particularly vulnerable to an extreme manifestation of these developments.

Finally, after theorizing these transformations and their drivers, we suggest some avenues for possible responses. In particular, we highlight that new approaches to regulatory institutional change and labor organizing will be essential to modernizing the restraints on corporate power in ways that can respond to the rise of platform capitalism. 


\section{Beyond Financialization and Fissurization}

The twentieth-century social contract rested on an ideal typical conception of the consolidated firm, in the mode of General Motors or Ford. Those firms were vast entities that employed tens of thousands of mostly unionized workers. They provided extensive benefits, such as healthcare and pensions, and featured career ladders that offered pathways for upward mobility within the firm. Furthermore, those corporate entities were visible, powerful, and well regulated in close relationships with the modern federal regulatory state. Indeed, in the United States specifically, the New Deal-era social contract essentially deputized those vertically integrated firms to advance the broader goals of an inclusive economy, channeling investment in productive ways and serving as conduits for safety-net benefits. ${ }^{9}$ Meanwhile, important background regulations such as antitrust laws and financial regulations prevented these firms from growing too big or diverting too much of their economic wealth into private rents or returns. In that way, the consolidated firm became a key vehicle through which the United States "improvised" a robust social contract even in the absence of a European-style social democratic political economy. ${ }^{10}$

However, as David Weil and especially Gerald Davis have emphasized, this ideal type was largely displaced in the 1980s and 1990s by a very different NOC firm - consisting of a complex set of interrelationships between lead brand firms and downstream counterparts supplying labor as well as upstream counterparts providing funds and investment. ${ }^{11}$ Whereas the mid-century firm was characterized by authority concentrated in the top executives and ownership dispersed among a large number of passive investors, the "shareholder revolution" starting in the 1970s and accelerating in the 1980s led to the dominance of investor interests in corporate governance. Those changes were seen as a way to promote efficiency and growth by disciplining firms to investor demands. ${ }^{12} \mathrm{In}$ practice, the result was that organized and moneyed investor groups exerted intense and coordinated pressure on managers, which punished public firms for engaging in longerterm investments at the expense of short-term returns. ${ }^{13} \mathrm{CEO}$ pay also boomed during that period, as managers increasingly operated in coalition with investor interests.

Those pressures resulted in a radically different organizational structure: a shift from large capital-intensive facilities to a model of aggressive outsourcing, franchising, and streamlining — what Davis calls "Nikefication" and Weil the "fissuring" of the workplace. That organizational form crucially signaled a retreat from "standard employment"-full-time, open-ended employment contracts attached to a package of benefits - as peripheral support functions from janitorial services to back-end functions were outsourced, and precarious forms of work with fewer (if any) benefits increased.

The fissuring of the workplace has dramatically altered the corporate landscape. A recent study revealed that five of the top twenty global employers in 2017 are so-called workforce solution companies that do not produce anything at all but instead simply supply outsourced labor to other companies on demand. ${ }^{14}$ Widespread fissurization has thus broken up what had been robust internal labor markets in large firms, which allowed for upward mobility with a range of different income levels and jobs within the firm. The transition from the mid-century to the NOC firm represents a significant 
shift in the social contract and the background political coalitions around the workplace: from a model of strong managers, backed by passive investors, in coalition with labor, to a model of powerful investors, deputizing managers to extract returns primarily through an attack on wages, benefits, and labor costs.

\section{Platformization as Recentralization and Consolidation}

Platform capitalism represents a new model, one that shares some key features with the previous NOC firm but departs from it in crucial respects. Platform firms such as Uber and Amazon were facilitated by previous developments such as the emphasis on shareholder value, financialization, and labor-shedding. But they combine these elements with new features to produce a distinct model of the firm that poses even more extreme challenges to the social contract.

These firms' labor strategy builds on and in many ways perfects innovations pioneered by the NOC. Although platform firms like Uber have been criticized for their "gig"-based labor model, this model is in many ways simply a continuation of previous trends. Just as NOC firms moved to increasingly outsourced, contingent, and precarious forms of work, so too do platform firms accelerate those trends. Indeed, platforms take those strategies to a new level by forgoing labor contracts altogether, relying on independent contractors for whom the firm bears no responsibility for wages or hours or benefits or anything else.

The shift to the platform firm, like the shift to the NOC firm, is made possible by new technologies. As Weil pointed out, the fissuring of the firm was enabled by technologies that lowered the cost of monitoring outsourced or franchised operations. Technology thus allowed lead firms to get the "best of both worlds"- - slashing labor costs and escaping regulatory oversight while at the same time exercising enormous control throughout their networks of outsourced, franchised, or contracted labor, production, and manufacture. ${ }^{15}$ Platform firms such Uber and Amazon take the dynamic further because the platform technology - above all, its massive datamining properties - enables ever more fine-grained control over workers, contractors, and third-party firms engaged on the platform.

Investors are still important, but the financial interests behind the new platform firms represent a different type of investor. This change marks a first distinctive feature of the platform firm, distinguishing it from the NOC model. The types of institutional investors behind today's most dynamic firms are not in the business of demanding positive quarterly profit reports; they are instead committed to the longer-term project of consolidating market domination. Uber, for example, has famously been operating in the red for several years now, and Amazon barely posts profits most quarters, yet investors are completely unfazed. ${ }^{16}$ Why? Because the name of the game for platform firms is to capture whole markets and achieve monopoly power even if in the short to medium run that means absorbing losses year in and year out. As Paul Langley and Andrew Leyshon emphasize with reference to platforms such as Google and Facebook, scale is crucial "to [their] capacity to cultivate and capture value," and investors are key allies in the "battle for market supremacy."17 
In addition to the conventional billionaire angel investor, promising platforms can now draw financing from a variety of sources: venture capital, private equity firms, and even international sovereign wealth funds now often play a critical role in financing promising platforms to scale up. Such sources of investment share similarities with long-term patient capital. ${ }^{18}$ Once Amazon had established its dominance in the book industry, investors did not press for short-term profits but instead underwrote the company's drive to use its considerable first-mover advantages to expand aggressively, including into a range of related markets (e.g., logistics). Moreover, as platform firms become more dominant, they became stable, reliable investments for other sources of capital such as pension funds.

The financial interests behind these companies thus are capable of-and regularly demonstrate - enormous patience relative to the relentless quarterly demands of the old shareholder value model. Nevertheless, it is not the kind of patience on which coordinated capitalism rested and that in Europe traditionally was exercised in the interests of firm stakeholders broadly defined. ${ }^{19}$ Quite the contrary: these developments represent a concentration of control in the interest of powerful managers and investors pursuing winner-take-all returns. ${ }^{20}$ As a result, competition in developed platform markets often winds up being highly oligopolistic and characterized by very high barriers to entry. ${ }^{21}$

That result points to a second key distinction of the platform firm model. Davis's characterization of the NOC firm stressed radical outsourcing of almost all productive capacity, which in his view would ultimately also fuel a new instability. The lack of the significant tangible assets and infrastructure characteristic of the NOC firm would lower costs of entry and leave even the most formidable firms open to challenge by new "pop up" enterprises. ${ }^{22}$ However, the most successful platform firms today have been able to consolidate and concentrate power in ways that signal durability, not fragility. The central importance of network effects means that platforms backed by powerful and patient investors enjoy tremendous first-mover advantages over wouldbe challengers. As Mordecai Kurz notes, "Once an innovative firm establishes platform dominance, size becomes an advantage ... [and the] cost and economies-of-scale advantages are almost impossible for competitors to overcome." Even if no single firm achieves monopoly control, strong oligopolies are well positioned to "inhibit, or sharply constrain, further entrepreneurial efforts." ${ }^{23}$ Moreover, the most successful platform firms also demonstrate enormous capacity to anticipate and absorb potential competitors, sometimes to extend their own reach and sometimes just to quash a potential threat. These patterns are likely to continue in a world where traditional publicly funded firms are declining in favor of these more privately and venture-backed business models. ${ }^{24}$

The power of platform firms is thus not just anchored in the investors behind them; it derives as well from the way network effects allow the firms to secure concentrated "infrastructural power" that enables other forms of rent and revenue generation. ${ }^{25}$ This market dominance very much echoes classic concerns of monopoly power from a previous era. But today's platform giants exercise monopoly control without the burden and responsibilities of direct ownership. In contrast to the classic model of the 
vertically or horizontally integrated monopolistic firm that achieves and maintains its power through mechanisms of ownership or acquisition, the platform firms - although often built through mergers and acquisitions as well-exercise market power by controlling other participants on either side of the platform. Thus, for example, Uber can dominate both drivers and riders and set the terms for both sets of users that make up the market. Similarly, Amazon's retail platform structures and monetizes the interactions of vast numbers of consumers and sellers.

Exercising enormous control both upstream and downstream, these firms enjoy tremendous power over producers, workers, and other partners who all depend on the platform for access to consumer dollars. ${ }^{26}$ Some of these firms increasingly dominate whole supply chains by securing control over critical nodes in the flow of commerce: retailers cannot survive unless they work through Amazon; content creators cannot survive unless they flow through Google or Facebook. ${ }^{27}$

A third distinguishing feature of platform firms is their relationship to consumers. The concentration of power in platform firms is often rationalized and defended under the banner of serving consumer interests. Consumers were important to NOC firms, and they remain important for platform firms for some of the same reasons. In both cases, it is the ability to deliver lower prices and more seamless consumer experiences that generates market share and revenue, which in turn yield investor returns. Advantages in price and convenience are won through the flexible arrangements described above, and labor is reduced to an unwelcome "cost factor" to be minimized. Thus both models in effect sanctify the subordination and increasing "precarity" of producers and workers by delivering for the modern consumer.

However, a large consumer base is if anything even more important to platform firms than to NOC firms because the business model turns so heavily on achieving scale. Loyal consumers (in some cases more or less captive, because of high switching costs) are enlisted, actively or passively, as vital political allies. As noted above, platform firms enjoy an especially close, virtually unmediated, connection to their consumers that opens possibilities for explicit weaponization of the user base in political battles with regulators at all levels. Uber pioneered and perfected the strategy of using its app to mobilize consumers and apply pressure on politicians through social media campaigns. The most famous example was the "De Blasio" app, named for the New York City mayor who proposed limiting the number of Ubers. The company responded by adding a tab to its app through which users could register their disapproval to the city government with the push of a button. ${ }^{28}$ As Collier, Dubal, and Carter emphasize, Uber channels how the preferences of "the public" are presented through the aggressive use of social media, "solving" consumers' collective action problems while also controlling the message they send to policymakers. ${ }^{29}$

Moreover, consumers of those platforms that do achieve scale can become essentially locked in. Target and Walmart and Nike appealed to their consumer base (on price or on brand), but the relationship of consumers to firms such as Amazon and Uber runs much deeper, as these platforms have come to form part of the infrastructure of their lives. ${ }^{30}$ Once in place, the power these firms wield takes on "second face" characteristics. $^{31}$ The political terrain becomes tilted in favor of the platform, as 
politicians rationally shy away even from entertaining policies that would deprive their constituents of the convenience so many of them have become accustomed to and indeed now rely on. Rare is the politician who wants to alienate her constituents by shutting down their access to cheap consumer goods delivered the next day through Amazon Prime or to the information gateway that connects them to their friends and families through Facebook.

This alliance with consumers - whether explicit or tacit - further distinguishes today's platforms from other types of monopolies past and present. Like other monopolies, the efficiency gains of today's platforms are a function of their scale and scope. But unlike past monopolies, consumers often do not experience the power of the platform as an unwelcome constraint. On the contrary, many platforms (at least at this stage in their development) feel to the consumer like liberation-from having to flag down a cab in the pouring rain (Uber) or from the need to waste precious time circling for a parking spot at the mall (Amazon). In this situation, consumers become natural allies of platforms, similarly hostile to regulations that threaten to deprive them of newfound freedoms and conveniences. In short, today's platforms often exercise power not against the public but in a close and symbiotic alliance with a public that loves and depends on them. ${ }^{32}$

A close relationship with consumers is a crucial source of durability: it helps legitimize the entire business model; it often plays a central role in the rhetorical arguments these firms advance when pressuring regulators to give them more leeway. In this way too, platform firms represent an exacerbation of previous dynamics, as consumer support further amplifies the political power of the platform firm and helps accelerate its push for market dominance and, in some cases, the suppression of labor.

\section{The Changing Politics of the Firm}

Platform firms thus represent a distinctive shift from both the mid-century model of the firm and the late-twentieth-century NOC firm. The new platform model rests on a novel political coalition. Here our analysis takes inspiration from, but also extends, Peter Gourevitch and James Shinn's seminal work on corporate governance. ${ }^{33}$ Gourevitch and Shinn challenged traditional accounts that focused exclusively on owners and managers by incorporating attention to labor as well. They explored distinctive corporate governance regimes produced cross-nationally by different coalitional alignments among owners, managers, and workers. Leaving all nuance to the side, they identify two broad models: a diffuse shareholder model, often underpinned by a coalition of owners and managers, and a concentrated blockholder model supported by managers and labor.

Gourevitch and Shinn do not consider how consumers figure in the coalitional politics behind diverse corporate forms, although they do identify an apparent connection between their analysis and that of Ronald Rogowski and Mark Kayser, in which consumers do figure prominently. ${ }^{34}$ Specifically, they note that the same majoritarian electoral institutions that appear to support the shareholder model in their own analysis also tend to favor consumers. ${ }^{35}$ Neither study, however, fleshes out the politics that explain the link. 
Although a full analysis lies well beyond the bounds of this article, we begin to draw out the political dynamics, at least for the platform business model, by contrasting developments in the United States to other more coordinated market economies in Europe.

Our contention here is that platform firms rest on a new investor-consumer alliance, one brokered by powerful managers and representing a fusion of the financial powers of their investors and the political clout of their carefully cultivated user base. The combination is distinctive in being simultaneously patient and hostile to labor: both investors and consumers are served by reducing labor costs to lower prices and to slim down the firm. It is important that both are also served by the platform firms' focus on achieving market dominance, which secures winner-take-all returns for investors while maximizing consumer ease and welfare, although often at the direct expense of labor.

The combination of investor and consumer interests around a business model that seeks market dominance and cuts labor out of the modern social contract is politically and rhetorically powerful. It allows platform firms to portray themselves as defending consumers against "stifling" regulation in the interest of efficiency, innovation, and consumer choice; it is especially potent because the business and investor interests are adept at not only reading the market but also navigating the policy landscape and overcoming countervailing pressures from labor and other stakeholders. As we will see in the next section, this coalition has proved particularly adept at navigating the legal and institutional landscape of policymaking in the American context.

\section{Facilitating the Rise of Platform Capitalism: The United States in Comparative Perspective}

The pioneering role played by US firms in the advance of the platform firm is often attributed to an entrepreneurial culture or the innovation-promoting features of a liberal market economy. Platform firms in the United States clearly benefited mightily from the technological lead resulting from US military spending on research and development. It is hard to imagine the emergence of this new corporate form without considering the role played by the US government, specifically the Department of Defense, in the development of the core technologies on which these firms are built. ${ }^{36}$ Moreover, and as Hall and Soskice emphasize, other features of US political economy also tend to support "radical" innovation over the more incremental technological change characteristic of Europe's coordinated market economies. ${ }^{37}$

Beyond the initial innovations, however, those technologies had to be adapted and brought to broad markets, and for that task, different factors come into play. Here, we wish to emphasize three structural features of the political landscape in the United States that have provided an especially congenial context for platform firms - in liberal Democratic and conservative Republican administrations alike - since the 1980s. First, the fragmentation of state regulatory capacity and the weakness of countervailing pressures, particularly from organized labor and rival business interests, provide the permissive context that "disruptive" market players require to gain a foothold. Second, features of the American legal regime, particularly the prevailing pro-consumer orientation of antitrust law, actively promote the new platform model and sustain the political coalition 
on which it rests. Third, the heavily financialized tilt of the American political economy and the availability of plentiful sources of patient capital — underemphasized in mainstream literature on comparative political economy - provide the resources that have fueled the growth of the new platform business model.

\section{A Permissive Political-Economic Landscape}

A core challenge posed by the rise of new corporate forms is that many of the strategies that they pursue are not well covered by a regulatory apparatus inherited from the industrial era. Indeed, today's most dynamic platforms often grew precisely by moving aggressively into legal gray zones - pushing the bounds of existing rules and creating wholly new markets beyond the reach of existing policies. Amazon, for example, established early dominance in the book industry and now in the broader retail sector in part by constructing its business before state, local, and federal officials had developed approaches to internet commerce. Some firms pursued even more brazen and open strategies of defying the law altogether. Uber famously launched operations across the globe that flagrantly ignored existing transit and taxi regulations, daring cities to confront them. ${ }^{38}$

Elizabeth Pollman and Jordan Barry coined the term "regulatory entrepreneurship" to characterize the strategy of engaging in activities where the laws are "unclear, unfavorable, or even prohibit the activity outright." 39 For regulatory entrepreneurs, challenging and ultimately changing the law is not just desirable; it is "a material part of [the] business plan." 40 These gray zones arise not only from the strategic exploitation at the edges of labor, financial, and other economic regulations ${ }^{41}$ but also from new technologies not yet regulated by government agencies.

The United States is not uniquely open to such strategies, but the country's distinctive political-economic landscape provides uncommonly fertile terrain for platform firms. First, the highly fragmented nature of the regulatory infrastructure inhibits a swift and coordinated response to the power-concentrating effects of the new corporate forms. Indeed, the strategic capacity of today's megacompanies dwarfs that of fragmented US jurisdictions and creates a power mismatch. Jurisdictional fragmentation figures prominently: cross-state competition gives firms leverage to extract concessions from state governments, as exemplified by the frenzy set off when Amazon announced plans for a second headquarters. Equally important, variation in regulations at the state and even the municipal level provokes a deregulatory race to the bottom as firms pursue changes in their favor. Uber for one exploited the fragmented US landscape to inspire competition among cities and thus to pressure them into accepting its presence and business model. ${ }^{42}$

Although European political economies are not immune to such strategies, they tend to be less congenial to them. Take the case of Germany, as strong a version of federalism as one finds in Europe. There, institutional arrangements such as financial equalization (which redistributes financial resources across states) and direct representation of state governments at the national level mitigate the impact of jurisdictional competition. Even the European Union in some ways imposes more constraints on 
competition among its member states than the US federal government does on its states. ${ }^{43}$ For example, EU rules prohibit states from offering selective aid to companies as a way to gain advantage in location decisions. There are exceptions, but they must typically be approved by the Commission.

Moreover, the vertical fragmentation of authority in the American political system is mirrored horizontally within the federal government. ${ }^{44}$ Wide gaps exist between the jurisdictions, energies, and attentions of the several regulatory agencies that oversee the economy. To take an example of significance for platform capitalism, the Department of Justice and the Federal Trade Commission share jurisdiction over antitrust enforcement, and the lines of authority between the two are blurry to say the least. Furthermore, in the less professionalized American bureaucracy, agency personnel often share a cultural and social background with business leaders that makes them more favorable to business interests. ${ }^{45}$ Even where regulators operate in good faith, lack of independent research and analytical capacity makes them dependent on industry for data, information, and basic tutoring in the complexities of modern financial and legal business arrangements. ${ }^{46}$ Weak (and in some cases openly permissive) securities enforcement by financial regulators is well documented and played a role in the financialization of the modern economy. ${ }^{47}$

Along with a relatively weak and fragmented regulatory apparatus, the US political economy also offers few societal backstops to the advance of powerful new concentrations of economic power. In Europe, organized labor often plays a strong role in checking the power of dominant corporate actors. However, American unions were already weaker than in almost any other rich democracy, and their strength has further declined over the past several years as organized labor's rights have been deliberately dismantled. In the United States a mere 10 percent of full-time workers (including public sector) are covered by union contracts, well below Western European levels that typically range from 50 to 95 percent. ${ }^{48}$

The problem is in large part structural. The core arrangements for organizing and representing workers under the National Labor Relations Act (NLRA) date back to the 1930s and are completely mismatched to current economic and firm structures. ${ }^{49}$ Unlike in Europe, the NLRA forces unions to organize individual workplaces one at a time. ${ }^{50}$ This model bears almost no resemblance to the twenty-first-century firm, with its vast networks of subcontractors, independent contractors, and freelancers. ${ }^{51}$ The fissuring of workforces that began in the 1980s poses more severe problems in the United States than in Europe, where encompassing unions often bargain for entire industries.

The platform companies that are the focus here rely especially heavily on independent contractors, a group that under prevailing labor law is banned from engaging in collective bargaining. Indeed, in the United States, attempts by platform workers to negotiate collectively have been met in some cases with employers' charging the workers with collusion. ${ }^{52}$ The EU Court of Justice, by contrast, has signaled openness to allowing freelancers to bargain collectively in some circumstances. A 2014 decision held that competition law "does not apply to arrangements among freelance substitute orchestra musicians that aim to improve their working conditions if they 
can be qualified as 'workers." ${ }^{53}$ The ruling expanded on the precedent set by Albany ${ }^{54}$ that collective bargaining agreements fall outside the scope of competition law; it did so by extending those protections to cover agreements with what is termed "false self-employed" workers as well. ${ }^{55}$

In European countries, organized labor has also been more successful in pioneering new forms of platform agreements to establish minimum pay and benefits ${ }^{56}$ or (where they cannot negotiate directly) to provide services that help freelancers gain access to prevailing pay and benefits. ${ }^{57}$ More generally, strong unions (and associated higher wages and more generous social benefits) mean that platform firms compete for workers in a very different labor-market environment, one in which it is more difficult to recruit labor to work under subcontractual conditions. Partly for this reason, a hotel cleaning platform in Denmark (Chabber) recently converted itself from a facilitator/platform to a temporary agency, a move that brought its workers under the collective agreement negotiated for the entire hotel and restaurant sector.

The trend in the United States is, if anything, in the opposite direction. The Supreme Court, for example, sided with employers in a recent ruling on the use of class action waivers in arbitration agreements. ${ }^{58} \mathrm{~A}$ large number of employees in the United States (nearly a quarter of nonunion employees in the private sector) sign away their rights to class action when they take a job. ${ }^{59}$ To bring claims against their employers, these workers must take their disputes to arbitrators and as individuals. The playing field is tilted decisively toward employers: lawyers are reluctant to take on small suits that promise small payouts, and workers reasonably hesitate to bring complaints with prospects so heavily outweighed by the potential costs, including retaliation.

But organized labor is not the only possible societal backstop and source of countervailing pressure. In Europe, disruptive market entrants with winner-take-all ambitions are also more likely to encounter strong headwinds from organized business interests. In Europe's coordinated market economies, strong and well-organized trade groups and employer associations are often among the keenest to inhibit the advance of would-be monopolists, particularly those perceived to achieve competitive advantage via illegitimate (or illegal) market strategies.

In the United States, for example, Uber could provoke competition across jurisdictions; and politicians across the political spectrum rushed to accommodate the company. By contrast, in Germany, national associations representing local taxi operators mounted a quick, coordinated response that interfered with Uber's ability to recruit drivers and build sufficient supply to drive prices down. ${ }^{60}$ In that context, the service failed to generate the cycle of increased supply (of drivers) and increased demand (by users) that in the United States allowed the company to establish a powerful presence even under conditions of legal uncertainty. In short, organized business interests have been a powerful countervailing force in many European countries. As defenders of a level playing field, business or trade groups are often important in heading off what they see as unfair, ruinous competition in otherwise well-functioning (because wellregulated) markets. 
In sum, structural features of the American political-economic landscape constitute an unusually permissive political context, with ample openings for aggressive, highly resourced firms to engage in the types of regulatory entrepreneurship that Pollman and Barry describe. To many of today's megacompanies, the famous Facebook motto "move fast and break things" means exploiting legal gray areas aggressively and in some cases flagrantly breaking the law as a matter of course. Firms backed by investors with deep pockets can often outlast their opponents - for example, by tying up labor advocates in protracted and expensive court battles. They can buy the time to entrench themselves in the market and then mobilize and weaponize their user base to pressure politicians to sanction their actions after the fact. By the time regulators and judges have caught up, these companies present themselves as too important, too popular, and too big to be undone.

\section{A Supportive Legal Regime}

Beyond the political-economic landscape of organized interest groups, central features of the American legal regime - in particular the pro-consumer orientation of antitrust theory and practice - make the United States singularly fertile terrain in which platform capitalism can thrive. In theory, antitrust law exists to prevent concentrations of market power of the sort that, say, Amazon has secured over the larger retail landscape. Even as the shareholder revolution was making it possible for rising financial and investor interests to alter the culture and practices of the modern firm, a similar revolution was underway in antitrust law. A growing number of scholars in the United States, viewing antitrust through the lens of consumer welfare, argued that so long as prices remained steady or decreased, concentrations of market control - especially through vertical rather than horizontal integration of firms - were efficient and "reasonable" under antitrust law.

The "Chicago school" of law and economics was the center of gravity of the movement, which began in the late 1960s as part of a broader pushback against what was seen as excessive government intervention in the area of antitrust. Robert Bork, who later became solicitor general under Ronald Reagan, launched an initial salvo in his dissent to the findings of the Johnson administration's Task Force on Antitrust Doctrine. Bork argued that firm size and concentrated industry structures are often reflections of efficiency gains and thus serve consumer interests. ${ }^{61}$ Over the next decade, Bork's views worked their way into the courts and antitrust bureaucracy before they were formally embraced in the new merger guidelines issued by the Reagan administration in $1982 .{ }^{62}$ Since that time, consumer welfare has represented the primary metric on which American antitrust enforcement depends. ${ }^{63}$

Europe has so far declined to embrace the United States' consequentialist approach to antitrust fully; it continues instead to view market concentration per se as a threat to competition and efficiency. Indeed, coordinated market economies such as Germany have essentially switched positions with the United States on this issue. Historically, Germany has taken a more permissive stance, actively countenancing cooperation between competitors as an efficient way to nurture industry. The country's cartels were 
dismantled after World War II, and Germany modeled its own competition laws and institutions on the American system. Since World War II, however, the country has not taken the same strong turn as the United States to a consumerist approach, in part because the "law and economics" movement that flourished in the US legal profession did not wield the same influence in Europe. ${ }^{64}$ The German Cartel Office (Bundeskartellamt) continues to stress competition and to argue against the "more economic approach," suggesting that it would be a mistake to abandon the country's own prevailing "practice of antitrust enforcement ... that has been developed and proven for decades." 65

The European Union, which has a more overtly deregulatory bias than many of the member states, has generally been more open to the US approach. The Commission's Directorate-General for Competition in fact specifically advocated moving in that direction. However, those initiatives have typically been watered down in the face of fierce resistance from legal intellectuals and antitrust professionals. ${ }^{66}$ The current Danish commissioner for competition, Margrethe Vestager, has established a strong reputation for aggressive enforcement, and the case against Google is a reminder of the difference.

In a sustained analysis of the evolution of competition law in the United States and the European Union, Daniel Gifford and Robert Kudrie document and explain the continued divergence between the two jurisdictions when it comes to antitrust. ${ }^{67}$ Although EU competition law embraces the same goals - and even echoes some of the language - of the American antitrust regime, Gifford and Kudrie find continued "substantial differences in practice." ${ }^{68}$ Like Ergen and Kohl, they emphasize the influence of the Chicago school and suggest that "the approach that now dominates the academy and the courts [in the United States is] utterly different from that prevailing prior to 1974." It is in the years since then, they argue, that a "huge gap" has opened up between EU and US jurisprudence. ${ }^{69}$

Gifford and Kudrie acknowledge more recent pressures for convergence and even some signs of movement in European antitrust practice, but they insist that the process is slow and halting. They argue that different political traditions - instantiated in differences in the role of the state and organized interests in the economy-play a large role in explaining the continued "profound difference in approach" in US and EU antitrust on a number of important dimensions. ${ }^{70}$ In particular, Europe never developed the same strong antistate tradition, nor (with the exception of the UK) did it produce major political parties dedicated to minimizing the role of the state in the market. On the contrary, the dominant center-right and center-left (Christian democratic and social democratic) parties in Europe both accept a stronger role for the state and the social partners (organized business and unions) in the governance of the economy. Mainstream parties in Europe also tend to share a concern that concentrations of economic power are associated with unwelcome concentrations of political power. Thus, Gifford and Kudrie note, European countries tend to give more weight to social justice concerns than to the efficiency concerns that figure so prominently in the United States. ${ }^{71}$

All these differences are reflected in contrasting approaches to competition law, despite similarities in the texts. EU law, for example, is especially attentive to the 
possibility that dominant firms may abuse their market power, and "abuse of a dominant position" is more likely to be met with official intervention in Europe than in the United States. ${ }^{72}$ The much greater concern European authorities often exhibit for the competitors and commercial customers of dominant players reflects the existence of a "European reflex against disruptive change and in favor of 'fairness' toward market participants." 73 Most important in the present context, Gifford and Kudrie note a greater skepticism in Europe vis-à-vis what they call "new economy" firms in innovation-intensive sectors. They note that in those cases, US antitrust law has struggled to strike a balance between the goals of promoting innovation and counteracting overweening market power. By contrast, the European Union "has refused any special consideration for new economy firms." Here, too, they observe the continuing "pull of maintaining rivalry or serving other objectives beyond directly promoting consumer welfare" in EU competition policy. ${ }^{74}$

In sum, and in contrast to Europe, US antitrust law not only supports but explicitly reinforces and entrenches the pervasive ideology of consumerism in the United States. Companies such as Amazon and Uber know how to take full advantage; they never cease to emphasize the benefits offered consumers in the form of better service and, at least for Amazon, lower prices. The appeal to consumers does more than insulate these firms against potential antitrust enforcement; it also creates a broader sense of social legitimacy and even active political support for these companies against government regulation.

\section{A Financialized Business Sector}

Finally, the business strategies of platform firms, as we have seen, depend heavily on a particular type of investor, one willing to underwrite massive losses in the short and medium term in pursuit of winner-take-all gains. Peter Thiel, now an active venture capitalist who himself founded a hugely successful platform (PayPal), captures the logic: "If you're the founder . . . entrepreneur starting a company, you always want to aim for monopoly and you always want to avoid competition." 75 Finance is thus a critical ingredient, and the US political economy is again particularly well suited to provide it.

By almost any measure, the level of financialization is far higher in the United States than in Europe. ${ }^{76}$ Greta Krippner has documented the growing importance of financial activities in the American political economy since the $1980 \mathrm{~s}^{77}$ The financialization of the American political economy profoundly altered the business landscape and culture. Even classic mid-century concentrated firms such as Ford, General Motors, General Electric, and Sears have long since shifted their internal profit-making strategies, developing financial products as an increasingly important source of profit. ${ }^{78}$ Europe's coordinated market economies, by contrast, generally continue to exhibit a stronger continued commitment to industry. Although Europe was not immune to the shareholder value revolution, stronger traditions of family ownership, more robust unions, and more resilient social partnerships have also kept many companies more committed than their American counterparts to the traditional long-term time horizons characteristic of the mid-century firm. ${ }^{79}$ 
As we have emphasized, the types of financial interests that stand behind today's platform firms also exhibit extreme patience, although the motives are quite different from the patient capital model long associated with coordinated market economies. Venture capital (VC) markets - more developed in the United States than in most coordinated market economies - play a key role here. ${ }^{80}$ But in the meantime, even the private equity firms that were so active in the Nikefication movement of the 1980s are central players as well, bankrolling platform firms while they achieve scale as share values soar on the promise of even greater downstream rents. ${ }^{81}$

The strategic relationship between managers and investors is not new to platform capitalism, but it takes a distinctive form, especially since many of the paradigmatic platform firms such as Amazon and Uber have emerged through close relationships between firm founders on the one hand and venture capital on the other. Long having played a pivotal role in assembling funds to finance promising new startups, ${ }^{82} \mathrm{VC}$ firms were the major seed investors in Amazon, Google, Apple, PayPal, and many other tech giants and today account for close to $\$ 84$ billion per year in startup capital..$^{83}$ Some VC firms actively participate in cultivating a new startup's business model, suggesting personnel or business plan modifications. Alongside funding from individual "angel investors," VC funding carries with it a mark of prestige in Silicon Valley, with VC firms playing "king-maker" among competing tech startups. ${ }^{84}$

Although VC and angel investors certainly demand high returns, they can also operate as patient forms of capital, shielding firms from short-term market imperatives and allowing them to focus on long-term value creation rather than short-term profits. ${ }^{85}$ The model of the patient investor seeking the rare, extremely high-return investment leads to unusual business strategies that arise from the joint interests of VC investors and startup leaders. First, both VCs and startups are highly incentivized to pursue winner-take-all strategies. With the advantage of significant reserves of investment capital, these firms can swing big - provided they eventually secure market dominance at a scale large enough to justify the investment. Second, reserves of investment cash plus the incentive to scale up quickly and at any cost encourage the kind of risk taking and aggressive regulatory strategies that mark, for example, Uber, with its track record of ignoring or blowing past regulatory barriers and legal liabilities in the race for market dominance. ${ }^{86}$ Indeed, VCs and angel investors seem actively to gravitate toward such "disruptive" business models.

The explosive success of aggressive winner-take-all strategies has had a broader transformative effect. Among other things, this new business model has inspired a search for additional new arrangements that can accommodate longer time horizons. One such arrangement is the idea of a long-term stock exchange (LTSE) currently being spearheaded by Eric Ries, a Silicon Valley entrepreneur. The core concept is to "create an exchange that is focused on the needs of companies with a long-term vision and investors who are similarly aligned." ${ }^{87}$ Private equity firms in the past have not been known for their patience; in fact, they were behind the "break it up and sell it off" movement of the 1970s and 1980s. However, they always had the option to be patient rather than predatory. The early successes of platforms (and associated soaring share values based on optimistic forecasts by security analysts) have increasingly drawn private equity firms into the game as well. 
Venture capitalism has evolved beyond incubation funding into the kind of large and stable source of patient capital that has been so important in underwriting the platform business model. Securities analysts continue to play an outsized role in US financial markets, and in that sense the same forces that drove the NOC model of radical streamlining now are providing the impetus for the emergence of more patient forms of capital. At the same time, however, there has been a shift in the mode of financing - away from the hyper-competitive ("break it up") approach associated with the NOC model toward a more anticompetitive model that supports the drive for concentrations of power that suppress competition. Not "core competencies" but network effects, potential for market dominance, and explosive and perpetual returns now justify a much longer time horizon of patience from investors and forge a strategic unity between investors and firm managers in pursuing winner-take-all strategies - and in absorbing the legal costs of regulatory arbitrage or boundary pushing along the way.

\section{Countervailing Power, Regulation, and Restraint on the Platform Firm}

The rise of the platform firm thus owes much to the political power and influence of business and financial interests in evoking the support of consumerist ideals and exploiting the weaknesses of the American political landscape. This new model built on several important changes that earlier gave rise to the NOC firm; it accelerated some - such as the continued assault on organized labor — and shifted others - such as the move from impatient to patient investor influence. Our diagnosis suggests that, from a political economy perspective, responses to the inequalities and instabilities created by the shift to the platform model of the firm must address the institutional and political features that created such imbalances of power and influence in the first place.

It is crucial that responses consider the imbalances arising from both late-century NOC firms, such as the fissured workplaces in retail and other sectors, and the newer, technology-based platform firms, such as Uber and Amazon. More vigorous enforcement of existing labor laws would bolster worker protections, but current developments clearly call for further changes, such as closing the loophole of employee misclassification by updating definitions of "employee" and "independent contractor." However, even those reforms would not address the underlying structural power disparity between employers and workers, particularly as employers would still retain the flexibility to define occupations strategically to exploit legal gaps and boundaries. ${ }^{88}$ More meaningful and durable change would thus require major reform of labor laws to make organizing workers more effective in the context of a fissured and platformized economy.

Labor law scholars have noted that union organizing and collective bargaining under the NLRA is weak in part because it lacks adequate protections against employer resistance. There are, of course, proposals that might limit employers' ability to pressure workers or make it easier for workers to form unions, through "card check" legislation for example. However, a deeper, more structural problem is that the NLRA was based on a traditional model of industrial work very distant from the norm in today's fissured and service-oriented economy, in which workers are dispersed and more difficult to 
organize. ${ }^{89}$ As Andrias puts it, "The law is structured around an ideal—or imaginedlabor management relationship that, for the most part, no longer exists." ${ }^{\circ 0}$ Given the transformations of the modern workplace, as several organizers and labor lawyers have suggested, a more radical reimagining of worker power is necessary.

In practice, the proliferation of new models of labor activism represents attempts to overcome the problems we have identified. Worker centers, for example, organize workers not around any particular employer or workplace but rather as members of a shared minority group, or residents of a local community, or employed across a broadly similar industry, such as restaurant workers, domestic workers, or guest workers. Groups such as the National Domestic Workers Alliance and campaigns such as Justice for Janitors have been forerunners of the worker mobilization that has gained success in recent years in the push for a $\$ 15$ minimum wage. ${ }^{91}$

More effective modes of worker organizing that build on these innovations, however, require far-reaching structural legal change. Eliminating the prohibition on secondary boycotts, for example, would free workers from being locked into particular bargaining units and allow them to form a wider range of representative organizations. ${ }^{92}$ Furthermore, labor law would need to shift its focus from workplace-based organizing centered on the immediate demands of a particular group toward sector-based organizing with social demands that extend well beyond wages and worker standards..$^{93}$ As part of the "Fight for 15 " minimum wage campaign, for example, restaurant workers directed their efforts at key corporate owners and investors behind major restaurant chains rather than at individual restaurants. Such initiatives underscore the fact that countervailing labor power will have to confront the concentrations of power that have exercised widespread influence on workers in the first place.

These labor-empowering measures are essential to overcome the challenges posed by both the NOC firm of the fissured workplace and the platform firm, as both models rest on a shift in power from workers to firms and investors. Indeed, one of the most important ways to counter the problematic trends we have identified is to create new forms of twenty-first-century worker power capable of advocating in opposition to modern business and finance lobbies. Thus a revamped labor movement would need to pay attention not only to labor law and worker rights but to the full range of legal regimes that structure corporate power.

The unique characteristics of platform business models may necessitate further alternative strategies. Countervailing power in a platform economy must become more adept at advocating for changes in the securities laws that facilitate patient but unaccountable venture capital financing, for example. Lax antitrust enforcement has enabled both monopsony power in local labor markets and the predatory pricing schemes central to such firms as Amazon or Uber. Greater antitrust enforcement could, for example, limit the platform firms' ability to achieve market dominance, while closer regulation of platform firms could ensure that they treat all businesses and counterparts fairly ${ }^{94}$ Financial regulation, similarly, might address some patterns of investor power and spur more investment in startups and "real economy" firms.

Responses to the power and influence of the platform firm require shifting the coalitional and political economic dynamics that have given rise to these new forms of 
corporate organization and power. As noted above, the confluence of investor interests on the one hand and consumerist values on the other has proved a powerful political force helping promote and legitimize the rise of the platform firm. Left out of this coalition are the interests of producers and workers. But these are not the only ways to organize coalitions in twenty-first-century capitalism. We can imagine consumer-producer coalitions that share a common distrust and fear of concentrated private power. That kind of coalition played a large role in the Progressive Era and the New Deal and inspired important political-economic transformations - such as antitrust law, labor law, and consumer protection regulations - which together helped produce the dynamics of twentieth-century capitalism.

Finally, we can also imagine alternative coalitions of workers and consumers forming around a range of issues from privacy to social dumping. That approach is being taken, for example, by Sweden's largest union, Unionen, which organizes white-collar workers at all skill levels throughout the private sector. Swedish unions have traditionally been very accepting of innovation, and Unionen has taken a characteristically positive stance toward new platform business models while insisting that their competitive advantage not be achieved through social dumping. ${ }^{95}$ The union is pushing new platforms to sign existing collective agreements, but it ultimately has even more ambitious goals. One further initiative aims to make it easy for these firms to comply with labor standards by offering to work with their programmers to embed the relevant algorithms into the companies' own software. Invoking Lawrence Lessig's famous dictum that "code is law," the idea is to render compliance automatic and to reduce regulatory transaction costs for platform firms. ${ }^{96}$

A complementary tack, more prominent in Denmark, has been to enlist consumers as allies in the effort to regulate companies. This strategy seeks to capitalize on the power of companies' own user bases and to use the importance these firms assign to their images as a source of leverage. Denmark's largest union, 3F, waged a very successful public campaign against Uber, charging the company with drawing on Danish infrastructure (hospitals, roads, schools) while shirking taxes. Such behavior, union representatives emphasized, was "not consistent with Danish contributory ways."97 Invoking norms of solidarity and drawing attention to the consequences of social dumping and tax evasion, Danish unions appealed to the interests of the public not as consumers but as taxpayers, with the argument that the country's social model was viable only so long as everyone paid his or her fair share.

\section{Conclusion}

There is an extensive literature on the political power of the modern corporation and on the influence exercised by business interests within the formal political process. There is also long-standing concern about the decline of labor and the rise of corporate power in the modern economy. This article adds to these discussions by highlighting how the nature of the modern firm itself has changed in critical ways over the past few decades and by illuminating the broader legal and organizational conditions that have facilitated that change. The ideal type of the twentieth-century consolidated firm as a 
large employer well regulated by government and in dialogue with organized labor has given way first to the fissured or Nikefied firm that operates as a nexus of contracts, through extensive networks of franchising, outsourcing, and labor-cost shedding. The rise of the NOC firm, in turn, has facilitated the emergence of a new vanguard firm: the twenty-first-century ideal type of the platform firm. In the platform model, the lead firm or brand is slimmed even further, offloading much of its labor force to contractedout partners, legally distinct entities that can provide labor more cheaply and flexibly. The platform firm is also marked by concentrated ownership and influence among investors, increasingly operating in alliance with consumers.

The rise of the platform firm thus represents a new development in the changing nature of work, the growth of inequality, and the eroding social contract. This transformation, we have argued, is not simply a product of natural or technological change; rather it is crucially tied to the political-economic landscape, particularly in the United States. The rise of the platform firm, in part through interaction with the political-institutional structure and the landscape of regulatory policy, introduces a further mechanism through which political and economic inequality interact. This diagnosis of the nature and origins of the platform firm suggests that responding to twenty-firstcentury inequality will require-beyond redistributive tax and wage policies - a change in political-economic dynamics that can address the concentrations of power and shifts of influence the platform firm represents.

\section{Acknowledgments}

For extremely helpful comments along the way, we thank Benjamin Braun, Frank Dobbin, Timur Ergen, Daniel Francis, Dan Galvin, Jacob Hacker, Peter Hall, Alex Hertel-Fernandez, Martin Höpner, Gunnar Trumball, Nick Ziegler, and the participants in the Columbia Workshop on the American Political Economy in Comparative Perspective, the MPIfG Workshop on New Directions in Political Economy, and the Harvard Seminar on State and Capitalism since 1800. We are grateful as well to the editorial board of Politics \& Society, especially our coordinating editor, Rina Agarwala, for their valuable input.

\section{Declaration of Conflicting Interests}

The authors declared no potential conflicts of interest with respect to the research, authorship, and/or publication of this article.

\section{Funding}

The authors received no financial support for the research, authorship, and/or publication of this article.

\section{Notes}

1. Elizabeth Anderson, "The Business Enterprise as an Ethical Agent," in Subramanian Rangan, ed., Performance and Progress: Essays on Capitalism, Business, and Society (Oxford: Oxford University Press, 2015), 185.

2. Gerald Davis, Managed by the Markets (Oxford: Oxford University Press, 2009); Gerald Davis, "Corporate Power in the Twenty-First Century," in Rangan, ed., Performance and Progress, 395-414. 
3. Martin Kenney and John Zysman, "The Rise of the Platform Economy," Issues in Science and Technology (Spring 2016), 61, 66.

4. See especially Nick Srnicek, Platform Capitalism (Cambridge: Polity, 2017), chap. 2, as well as the interview with Zysman and Kenney in Reinvent (November 6, 2017), https:// medium.reinvent.net/who-has-the-power-the-answers-in-the-data-9678ef0f87e3.

5. John Zysman and Martin Kenney, "The Next Phase in the Digital Revolution," Communications of the ACM 81, no. 2 (2018), 62.

6. Ibid., 59, 62 .

7. See especially Carles Boix, Democratic Capitalism at the Crossroads? (Princeton, NJ: Princeton University Press, 2018).

8. See also Kenney and Zysman, "Rise of the Platform Economy."

9. Davis, "Corporate Power in the Twenty-First Century"; Nelson Lichtenstein, "Two Cheers for Vertical Integration: Corporate Governance in a World of Global Supply Chains," in William Novak and Naomi Lamoreaux, eds., Corporations and American Democracy (Cambridge, MA: Harvard University Press, 2017), 333-36.

10. Gary Gerstle, Liberty and Coercion: The Paradox of American Government from the Founding to the Present (Princeton, NJ: Princeton University Press, 2015).

11. Davis, Managed by the Markets; Davis, "Corporate Power in the Twenty-First Century"; David Weil, The Fissured Workplace: Why Work Became So Bad for So Many and What Can Be Done to Improve It (Cambridge, MA: Harvard University Press, 2014).

12. See, e.g., Henry Hansmann and Reiner Kraakman, "The End of History for Corporate Law," Georgetown Law Journal 84 (2001); Lucian Bebchuk, "The Case for Increasing Shareholder Power," Harvard Law Review 118 (2005).

13. Frank Dobbin and Dirk Zorn, "Corporate Malfeasance and the Myth of Shareholder Value," Political Power \& Social Theory 17 (2005): 179-98; Lynn Stout, "The Toxic Side Effects of Shareholder Primacy," University of Pennsylvania Law Review 161, no. 7 (2013); Weil, Fissured Workplace, 46-48.

14. Lauren Weber, "Some of the World's Largest Employers No Longer Sell Things, They Rent Workers," Wall Street Journal (December 28, 2017).

15. Weil, Fissured Workplace, chaps. 5-7.

16. See, e.g., Nick Wingfeld, "Amazon Profits Fall Short of Expectations, but Investors Shrug," New York Times (July 27, 2017), (https://www.nytimes.com/2017/07/27/technology/amazon -second-quarter-profits.html?smprod=nytcore-ipad\&smid=nytcore-ipad-share\&_r=0).

17. Paul Langley and Andrew Leyshon, "Platform Capitalism: The Intermediation and Capitalization of Digital Economic Circulation," Finance \& Society 3, no. 1 (2017): 22, 26. See also Mordecai Kurz, “The New Monopolists," Project Syndicate (September 22, 2017). Kurz's study shows that monopoly wealth (defined as the component of stock values attributable to monopoly control as a share of total stock market value) has risen sharply since 1985 . Nine of the ten firms with the largest share of monopoly wealth are in IT-related industries.

18. Robyn Klingler-Vidra, "When Venture Capital Is Patient Capital: Seed Funding as a Source of Patient Capital for High-Growth Companies," Socio-Economic Review 14, no. 4 (2016): 691-708.

19. Peter A. Hall and David Soskice, Varieties of Capitalism (New York: Oxford University Press, 2001).

20. Kurz, "New Monopolists."

21. Jean-Charles Rochet and Jean Tirole, "Platform Competition in Two-Sided Markets," Journal of the European Economic Association 1, no. 4 (2003): 990-1029; Andrei Hagiu and Julian Wright, "Multi-sided Platforms," International Journal of Industrial Organization 43 (2015). 
22. Davis, "Corporate Power in the Twenty-First Century," 409-13.

23. Kurz, "New Monopolists." Moreover, for platforms that derive power from the information they gather on users, "their positions are enhanced by their ability to use their customers' private information as a strategic asset." See also Charles Duhigg, "The Case against Google," New York Times Magazine (February 20, 2018).

24. See Kathleen Kahle and René Stulz, "Is the US Public Corporation in Trouble?," Journal of Economic Perspectives 31, no. 3 (2017): 67-88.

25. K. Sabeel Rahman, "The Shape of Things to Come: The On-Demand Economy and the Normative Stakes of Regulating 21st-Century Capitalism," European Journal of Risk Regulation 7, no. 4 (2016): 652-63.

26. Ibid.; Lina Kahn, “Amazon's Antitrust Paradox,” Yale Law Journal (2017).

27. Kahn, "Amazon's Antitrust Paradox"; Frank Pasquale, Black Box Society: The Secret Algorithms That Control Money and Information (Cambridge, MA: Harvard University Press, 2015). These technology-enabled platforms thus represent a starker form of similar business models in "offline" sectors; as discussed earlier, retail and manufacturing networks have become organized along similar lines, with the lead brand managing upstream suppliers and downstream producers exercising widespread control over the supply chain. In the United States, Walmart represented the first expression of mass retail platform power, in a preinternet platform world, raising many of the same challenges posed by firms such as Amazon or Uber. See also Barry Lynn, Cornered (New York: Wiley, 2009).

28. Kathleen Thelen, "Regulating Uber: The Politics of the Platform Economy in Europe and the United States," Perspectives on Politics 16, no. 4 (2018): 938-53. In this case, the city government ultimately pushed back somewhat, but Uber has enjoyed unalloyed success with the same strategy in other cities.

29. Ruth Berins Collier, Veena Dubal, and Christopher Carter, "Disruptive Regulations: The Politics of Uber in the US," Perspectives on Politics 16, no. 4 (2018): 3.

30. For an extended analysis, see Pepper Culpepper and Kathleen Thelen, "Are We All Amazon Primed? Consumers and the Politics of Platform Power" (unpublished manuscript, MIT and Oxford University, 2018), on which we draw here.

31. Steven Lukes, Power: A Radical View (New York: Macmillan, 1974).

32. Many of today's biggest platforms are among the most popular companies worldwide. In the United States, for example, Google and Amazon rank first and fourth in popularity among firms (with 70 percent or higher approval ratings), according to a poll conducted by Morning Consult, available at https:/www.statista.com/chart/9214/americas-favorite -brands/. YouGov found that Google, YouTube, What's App, Facebook, and Amazon are all in the top ten according to their global brand health index, which was based on a survey tapping into "perceptions of a brand's quality, value, impression, satisfaction, reputation and whether consumers would recommend the brand to others"; https://yougov.co.uk/topics /consumer/articles-reports/2018/07/26/google-keeps-top-spot-yougovs-global-brand-health-.

33. Peter A. Gourevitch and James Shinn, Political Power and Corporate Control (Princeton, NJ: Princeton University Press, 2005).

34. Ronald Rogowski and Mark A. Kayser, "Majoritarian Electoral Systems and Consumer Power: Price-Level Evidence from OECD Countries," American Journal of Political Science 46 (2002): 526-39.

35. Conversely, proportional representation systems support Gourevitch and Shinn's blockholder model of corporate governance and reward producers over consumers in Rogowski and Kayser's analysis.

36. See Fred Block and Matthew Keller, eds., State of Innovation: The US Government's Role in Technological Development (New York: Taylor \& Francis, 2011). 
37. Hall and Soskice, Varieties of Capitalism.

38. Thelen, "Regulating Uber."

39. Elizabeth Pollman and Jordan Barry, "Regulatory Entrepreneurship," Southern California Law Review 90, no. 3 (2017): 384.

40. Ibid., 385.

41. See, e.g., Weil, Fissured Workplace.

42. Thelen, "Regulating Uber."

43. See Chase Foster, "The Politics of Delegation: Constitutional Structure, Bureaucratic Discretion, and the Development of Competition Policy in the United States and the European Union, 1890-2017" (PhD dissertation, Harvard University, 2018).

44. E.g., Margaret Weir, "States, Race and the Decline of New Deal Liberalism," Studies in American Political Development 19, no. 2 (2015): 157-72.

45. James Kwak, "Cultural Capture and the Financial Crisis," in Dan Carpenter and David Moss, eds., Preventing Regulatory Capture: Special Interest Influence and How to Limit It (New York: Cambridge University Press, 2013).

46. Wendy Wagner, "Administrative Law, Filter Failure, and Information Capture," Duke Law Journal 59, no. 7 (2010): 1321-432; Lawrence Baxter, "Capture in Financial Regulation: Can We Channel It toward the Common Good?," Cornell Journal of Law \& Public Policy 21 (2011): 175-200; Dan Awrey, "Complexity, Innovation, and the Regulation of Modern Financial Markets," Harvard Business Law Review 2 (2012): 235-94; Weber, "Structural Regulation"; Nicholas J. Ziegler and John T. Wooley, "After Dodd-Frank: Ideas and the Post-enactment Politics of Financial Reform in the United States," Politics \& Society 44, no. 2 (2016): 249-80.

47. Simon Johnson and James Kwak, Thirteen Bankers: The Wall Street Takeover and the Next Financial Meltdown (New York: Vintage, 2011).

48. The coverage rate in Switzerland is just below 50 percent. Japan, the United Kingdom, and Canada have coverage rates below 50 percent but in all cases still above the US level. The most comprehensive database is Jelle Visser's, http://www.uva-aias.net/en/ictwss.

49. Kate Andrias, "The New Labor Law," Public Law \& Legal Theory Research Paper Series, Paper no. 523 (Ann Arbor: University of Michigan Law School, 2016), 28.

50. For an extended comparison of the distinctive features of US labor law compared to Europe, see Kathleen Thelen, "The American Precariat: US Capitalism in Comparative Perspective," Perspectives on Politics 17, no. 1 (2019).

51. Andrias, "New Labor Law," 25, 28.

52. Uber drivers in Seattle, e.g., are currently fighting a legal challenge brought by the Chamber of Commerce for anticompetitive behavior.

53. See Laurens Ankersmit, "Albany Revisited: The Court Directs NCA to Carry a More Social Tune," European Law Blog (March 3, 2015), https://europeanlawblog.eu/2015/03/03 /albany-revisited-the-court-directs-nca-to-carry-a-more-social-tune/.

54. Albany International BVv. Stichting Bedrijfspensioenfonds Textielindustrie (1999) C-67/96, [1999] ECR I-5751, [2000] 4 CMLR 446.

55. "False self-employed" refers to those who are "engaged in paid work, without being able to independently determine their own conduct and without bearing the financial and economic risks of their entrepreneurship [and who therefore] fit far more into the category of 'worker,' as defined by EU law." Václav Šmejkal, "Competition Law and the Social Market Economy Goal of the EU," International Comparative Jurisprudence 1, no. 1 (2015): 41.

56. A pioneering trial agreement was recently signed by the Danish platform Hilfr and the United Federation of Danish Workers (3F); https://fagbladet3f.dk/artikel /rengoeringsplatform-indgaar-aftale-med-3f. 
57. In Ghent countries, e.g., platform workers can join union-controlled unemployment insurance funds. Some unions have also collaborated with private pension companies to create attractive insurance programs for platform workers, accessible only to those who join the union. See Anna Ilsoe and Louise Weber Madsen, Industrial Relations and Social Dialogue in the Age of Collaborative Economy: National Report Denmark (Copenhagen: University of Copenhagen, 2018), 22.

58. David Jamieson, "The Supreme Court Just Made It a Lot Harder for You to Sue Your Employer," Huffington Post (May 29, 2018), https://www.huffingtonpost.com/entry /supreme-court-sue-your-employer_us_5afb2bcde4b09a94524ca8f3?yfm. Employees at Google have recently mobilized against mandatory arbitration, resulting in changes at some high-tech companies.

59. Alexander Colvin, "The Growing Use of Mandatory Arbitration" (Washington, DC: Economic Policy Institute, September 27, 2017), https://www.epi.org/publication/the -growing-use-of-mandatory-arbitration/.

60. For a more complete comparative analysis, see Thelen, "Regulating Uber."

61. Timur Ergen and Sebastian Kohl, "Varieties of Economization in Competition Policy: A Comparative Analysis of German and American Antitrust Doctrines, 1960-2000," MPIfG Discussion Paper no. 17/18 (Cologne: Max Planck Institute for the Study of Societies, 2017), 9.

62. Kahn, "Amazon's Antitrust Paradox," 721.

63. Ibid.; Ergen and Kohl, "Varieties of Economization."

64. Ibid.; Daniel Gifford and Robert Kudrie, The Atlantic Divide in Antitrust: An Examination of the US and EU Competition Policy (Chicago: University of Chicago Press, 2015).

65. Bundeskartellamt statement from 2001, quoted in Ergen and Kohl, "Varieties of Economization," 18.

66. Ibid., 17.

67. Gifford and Kudrie, Atlantic Divide; see also Foster, Politics of Delegation, which documents divergence in competition policy practice in the United States and the European Union, despite the similarities in the laws on the books.

68. Gifford and Kudrie, Atlantic Divide, 3.

69. Ibid., 7, 13 .

70. Ibid., 17.

71. Ibid., 9-10.

72. Ibid., 10-11. See also Germán Gutiérrez and Thomas Philippon, "How EU Markets Became More Competitive Than US Markets: A Study of Institutional Drift,” NBER Working Paper no. 24700 (Cambridge, MA: NBER, 2018), 24, who find that while enforcement of "abuse of dominance" in Europe was stable or even increasing since the 1970s, it "has all but disappeared in the US." Their explanation of divergence on this dimension (alongside others) differs from that of Gifford and Kudrie. Like Foster (Politics of Delegation), Gutiérrez and Philippon suggest that the differences between EU and US antitrust policies are primarily differences in enforcement. They argue that the United States enforces competition policy less vigorously than Europe because US regulators are more exposed to political pressure (e.g., lobbying, need for campaign contributions) while their European counterparts, not similarly embedded in the domestic politics of any one member state, are more independent.

73. Gifford and Kudrie, Atlantic Divide, 11. This observation again resonates with Hall and Soskice's analysis in Varieties of Capitalism.

74. Gifford and Kudrie, Atlantic Divide, 16, 17. 
75. Rajen Sanghvi, " 32 Quotes from Peter Thiel on Business Strategy and Monopoly Theory," https://medium.com/how-to-start-a-startup/32-quotes-from-peter-thiel-on-business-strategy -and-monopoly-theory-6025a479fla7.

76. Except perhaps for the Netherlands and by some measures the United Kingdom. See Ewald Engelen, Martijn Konings, and Rodrigo Fernandez, "Geographies of Financialization in Disarray: The Dutch Case in Comparative Perspective," Economic Geography 86, no. 1 (2010): 53-73.

77. Greta R. Krippner, Capitalizing on Crisis: The Political Origins of the Rise of Finance (Cambridge, MA: Harvard University Press, 2011). Financial interests are also well organized politically, in a mode similar to the influential Business Roundtable. The Financial Services Roundtable includes the country's largest financial services companies.

78. Ibid.; also Rana Foroohar, Makers and Takers: The Rise of Finance and the Fall of American Business (New York: Crown Business, 2016).

79. Examples include the Wallenberg family in Sweden and the vast German Mittelstand.

80. Hall and Soskice discuss but do not highlight the role of venture capital, seeing it as an (important) exception to the dominant short-termism characteristic of the liberal-market-economy model. Hall and Soskice, Varieties of Capitalism, 29.

81. Jill Frisch, "The New Governance and the Challenge of Litigation Bylaws," Brooklyn Law Review 81 (2016). K.J. Marijn Cremers and Simone Sepe, "Institutional Investors, Corporate Governance, and Firm Value," Seattle University Law Review 41 (2018).

82. Venture capital emerged as a huge industry in the United States following a series of legal and historical developments starting the late 1960s and early 1970s. Kim-Mai Cutler, "The Unicorn Hunters," Logic 4 (2018), https://logicmag.io/04-the-unicorn-hunters/. Military funding for Silicon Valley tech firms began to recede in the 1960s, while regulatory policy changes relaxed "prudential investment" requirements for institutional investors like university endowments and pension funds, permitting them to invest at least in part in higher-risk securities. Capital gains taxes were also reduced from 49 to 28 percent during the Carter administration. The result was a boom in VC firms and the emergence of now famous VC entities such as Kleiner Perkins and Sequoia Capital.

83. Seung Lee, "Venture Capital Investing Hits \$84 Billion, Highest since Dot-Com Boom," Mercury News (January 11, 2018), https://www.mercurynews.com/2018/01/11/ venture-capital-investing-hits-84-billion-highest-since-dot-com-boom/.

84. Uber secured most of its seed funding from individual "angel investors" in its initial 2010 fund-raising rounds, eventually securing $\$ 16$ of the $\$ 18$ billion it raised from VC firms and other institutional investors. Similarly, Amazon's seed funding initially came from friends and family of Jeff Bezos; Kleiner Perkins, with an $\$ 8$ million investment, was the only venture fund to engage before Amazon's IPO in May 1997.

85. Richard Harrison, Tiago Botelho, and Colin Mason, "Patient Capital in Entrepreneurial Finance: A Reassessment of the Role of Business Angel Investors," Socio-Economic Review 14, no. 4 (2016): 669-89; Klinger-Vidra, "When Venture Capital Is Patient Capital." The patience of VC firms is of course bounded by the maturity period of the investments on which they themselves depend. Moreover, in some cases, that patience may be forced; some scholars note that VC investors may suffer from "investor lock-in": they are stuck with their investment and able to exit only at certain stages, such as when the startup issues its IPO or if they can find a secondary buyer for their shares. See, e.g., Daniel Ibrahim, "The New Exit in Venture Capital," Vanderbilt Law Review 65, no. 1 (2012): 2-48; Margaret M. Blair, "Reforming Corporate Governance: What History Can Teach Us,” December 25, 2003, Georgetown Law \& Economic Research Paper \#485663. 
86. Pollman and Barry, "Regulatory Entrepreneurship," 426.

87. Andrew Ross Sorkin, "Fixing the 'Brain Damage' Caused by the I.P.O. Process," New York Times (September 18, 2017), https://www.nytimes.com/2017/09/18/business/dealbook /ipo-chamath-palihapitiya.html?smprod=nytcore-ipad\&smid=nytcore-ipad-share\&_r=0.

88. Brishen Rogers, "Employment Rights in the Platform Economy: Getting Back to Basics," Harvard Law \& Policy Review 10 (2016): 479-519; Noah Zatz, "Beyond Misclassification: Tackling the Independent Contractor Problem without Redefining Employment," $A B A$ Journal of Labor \& Employment Law 26, no. 2 (2011).

89. Brishen Rogers, "The Promise of Libertarian Corporatism for Labor Law," Texas Law Review 94 (2016); Ben Sachs, "Enabling Employee Choice: A Structural Approach to the Rules of Union Organizing," Harvard Law Review 123 (2010); Cynthia Estlund, "The Ossification of American Labor Law," Columbia Law Review 102 (2002).

90. Andrias, "New Labor Law," 32-33.

91. See David Rolf, The Fight for \$15: The Right Wage for a Working America (New York: New Press, 2016).

92. Rogers, "Promise of Libertarian Corporatism."

93. Andrias, "New Labor Law."

94. K. Sabeel Rahman, Democracy against Domination (New York: Oxford University Press, 2017).

95. Fredrick Söderqvist, "Sweden: Will History Lead the Way in the Age of Robots and Platforms?," in Florian Ranft, Max Neufeind, and Jacqueline O'Reilly, eds., Work in the Digital Age (London: Rowman \& Littlefield, 2018), 295-304.

96. Ibid., 301-2; see also Kenney and Zysman, "Rise of the Platform Economy."

97. Author interview with representatives of 3F, March 2016. For more on this example, see Culpepper and Thelen, "Are We All Amazon Primed?"

\section{Author Biographies}

K. Sabeel Rahman (Sabeel.rahman@brooklaw.edu) is an associate professor of law at the Brooklyn Law School. He is the author of Democracy against Domination (Oxford University Press, 2017).

Kathleen Thelen (kthelen@mit.edu) is Ford Professor of Political Science at MIT. She is the author, most recently, of Varieties of Liberalization and the New Politics of Social Solidarity (Cambridge University Press, 2014). 